\title{
Study On The Training Mode Of Integrated Talents In Secondary And Higher Vocational Education-Example Of The Major In Mechanical Design And Manufacturing
}

\author{
Qingyun Meng
}

Department of mechanical engineering, Dalian vocational and technical college , Dalian ,China

Email:874702490@qq.com

Keywords: Integrated talents in secondary and higher vocational. Training model. Vocational education

\begin{abstract}
Training integrated talents of secondary vocational and higher vocational is the need of the social development and the vocational education development. This paper mainly analyzes the necessary of training integrated talents of secondary vocational and higher vocational and also researches the heart problems of it.
\end{abstract}

\section{The Necessary of Training of Integrated Talents in Secondary and Higher Vocational Education}

The Need Of The Development Of Social Industry. According to the results of team researching, among the employment enterprise with the students of the mechanical design major, the large and medium-sized enterprises accounted for about $90 \%$, the small businesses accounted for only about $10 \%$. The large enterprises labor concentrate, and main of them are new enterprises, which shows that new and expansion enterprises are increasing and the economic situation of the manufacturing is good.

The target of "two areas with one": the construction of the equipment manufacturing community and building the internationally competitive world-class equipment manufacturing base is implemented in our city, so the talents need of manufacturing enterprise is increasing, and there is a big gap of higher vocational education people. According to it, we expect in the next 3 years the equipment manufacturing base in Dalian needs more than 15000 people, and the college graduates are only about 150 people a year. There are more than 1600 manufacturing companies in Dalian, there is a big gap between the graduates and enterprises needs, the task of serving the local economy is still a long way to go.

The Needs Of The Development Of Vocational Education. The ministry of education on promoting the coordinated development of secondary and higher vocational education guidance (faculty into no. [2011]), the long-term plan for education reform and development in Liaoning province (2010-2020, medium professional education development plan in Dalian(2011-2020) were put forward that by 2020, establishing the modern vocational education system of adapting the transformation of economic development patterns and industrial structure adjustment, reflecting the concept of life-long education, coordinated development of secondary and higher vocational education, accomplish the " ten integration": the training goal integration, specialty setup integration, digest course system and teaching materials integration, teaching process integration, teaching resources integration, admission system integration, evaluation mechanism integration, teachers training integration, vocation guiding integration, running school by collectivization integration. Secondary and higher vocational school cooperate and design the integration of secondary and higher vocational education standard of mechanical design and manufacturing major 
in, training the different level of skilled people that meet the needs of industrial cluster and processing and manufacturing enterprises. This is the need of the development of vocational education.

The Needs Of Building A Learning Society. Construction the learning society of life-long education is always the important concept that influences the world education. Strengthening the middle-high vocational education integration, building a modern vocational education system meets the needs of the people received vocational education and also meets the needs of high-quality workers and skilled people by satisfy the economic society is the objective requirement of establishing learning society, and also the needs of the development of person and life-long learning.

The country, the Liaoning province and city of Dalian all put forward that, by 2020, establishing the modern vocational education system of adapting the transformation of economic development patterns and industrial structure adjustment, reflecting the concept of life-long education, coordinated development of secondary and higher vocational education. Secondary and higher vocational school cooperating and designing the integration of secondary and higher vocational education standard is the need of National and local economic development, and also the need of vocational education development

\section{The Main Problems of Secondary and Higher Vocational Education Integration}

Lacking Of The Training Objectives Engagement. Don't work out the specific standard of professional teaching, there is no systematic research of professional ability that secondary and higher vocational students should have. Secondary vocational students' ability to accept continuing education are not enough, mainly show in academic foundation is weak. Higher vocational education focus on theory education, the demand of theory is higher, theory demands more than practice. That leads the training target of the two phases disconnected, theory of secondary education to the higher vocational education lacks of continuity, skills training lacks of deep going. That makes the difficulty of training, and hard to accomplish the integration of people.

Lacking Of The Curriculum System Engagement. Didn't work out the curriculum system of higher vocational integration, similar courses in higher vocational colleges is repeated, for example of the mechanism of professional, the mechanical drawing, mechanical and machinery manufacturing technology about 10 week theory courses and 10 weeks practical teaching obviously have curriculum content repetition, knowledge and skill points are parallel, which makes the teaching resources waste. At the same time, the same secondary and higher vocational courses have no connections, there is no period and progressive teaching, which limits the growth of students' knowledge and skill levels. In addition, affected by the employment pressure, the training of secondary vocational students over-focus on skills, theory teaching is weak; higher vocational education tend to focus on theory teaching more than practice teaching, that makes the integration by theory or practice of curriculum system difficulty.

Lacking Of The Teaching Methods Engagement. By the lack of penetration and communication between secondary and higher vocational schools, higher vocational schools don't establish the independent course system and evaluation model which suits secondary vocational students' characteristic. Most teachers are accustomed to high school students teaching. Don't know the characters of the secondary vocational student, lacking of education teaching methods, which leads to the inefficiency of the teaching. 
The Research of the Key Issues of Training Mode of Integrated Talents in Secondary and Higher Vocational Education

\section{By The Goal Of Training The Students' Vocational Ability In Period, Make Sure The Training} Targets Of Secondary And Higher Vocational Education. The ministry of education on promoting the coordinated development of secondary and higher vocational education guidance is pointed out: "the secondary vocational education is an important part of high school education, the point is cultivating skilled talents, playing a fundamental role; higher vocational education is an important part of higher education, the point is cultivating high skilled talents, play a leading role." The guidance expressly points out the specific training target of secondary vocational education and higher vocational education. In the secondary and higher vocational education integration, the target is not just limited to find a job, which should cover the target to continue study in higher vocational school, the training goal should accord to the needs of higher vocational training, which aims at training students who be able to do the learning task in higher vocational school. According to that, although the goal of higher vocational education has not changed in secondary and higher vocational education integration, but compared with the lack of professional knowledge and skills of high school students, secondary vocational students' professional theoretical level and skill level should be more improved, which meet the target of training high skilled talents, which shows the superiority of the secondary and higher vocational education integration.

The Target Of Secondary And Higher Vocational, Build The Scientific Secondary And Higher Vocational Curriculum System. The first of construction of secondary and higher vocational education integration is to clear every stage of the teaching contents and teaching emphasis; efficiently implement the training target of complementation, progressive and improving. Avoid the faults, disjunction and unnecessary repetition in secondary and higher vocational education, and avoid to cause the unnecessary waste of resources to ensure each stage graduates' every training ability. Second should design the engagement of curriculum standard and teaching plan in secondary and higher vocational education, explicit course objectives, content framework and assessment methods. Finally should make overall planning and integrated design in the choosing of teaching material, teaching methods and means, and the experiment bases, which forms a coherent and orderly secondary and higher vocational education integration.

The Training People By Secondary And Higher Vocational Education Schools, Build Scientific Secondary And Higher Vocational Education Curriculum System. In order to achieve the secondary and higher vocational education integration, except to integrate the target of secondary and higher vocational education and build secondary and higher vocational education curriculum system, the key is making the secondary and higher vocational education integration into specific teaching activities. The high quality teaching team is the important guarantee to achieve the integration of professional personnel training mode. In order to make the secondary and higher vocational education integration into the class and practical teaching, should begin with the following two aspects

Establish a Communication Teaching Mechanism for Secondary and Higher Vocational Education Integration. Leading by higher vocational schools, cooperated of secondary vocational schools, the higher vocational colleges and secondary vocational schools research together, clear each teaching emphasis, overall planning, and rational design. Encourage teachers doing specific research in teaching content, teaching methods, teaching process, students' condition, and textbooks to achieve the teaching design and teaching implementation of secondary and higher vocational education integration progressively.

Teachers Team Construction of Secondary and Higher Vocational Education Integration. The 
secondary and higher vocational education integration finally depends on the quality of teaching faculty. In fact, the teachers of secondary and higher vocational education have a certain gap in vocational knowledge ability level, teaching idea, teaching method and teaching ability. According to it, the higher vocational schools play a leading role, combine the teaching management of secondary and higher vocational education schools, propose specification teachers construction scheme, make the plan the training of the secondary and higher vocational education teachers, put them into the unified management system, form a standardized teacher evaluation system.

Following The Goal Of Outputting High-Skilled People, Ensure The Quality Of Professional Training. Solute the problem of secondary vocational graduates in higher vocational schools admissions test, ensure to the quality of the higher vocational school students, make sure them have the ability to finish higher vocational stage of learning tasks. Solve the problems of secondary vocational graduates' studies in higher vocational school, teaching process, evaluation mechanism, training the people who conform to the requirements of high-quality skilled personnel, ensure the "export" quality of higher vocational stage.

\section{Acknowledgement}

In this paper, the research was sponsored by the researching results of 2016 Dalian vocational and technical education scientific research topic "Study on the training mode of integrated talents in secondary and higher vocational education in Dalian, example of the major in mechanical design and manufacturing". (Project number: DZKY2016B01, topic moderator: Qingyun Meng)

\section{References}

[1] National medium and long-term plan for education reform and development(2010 2020)[Z].Beijing: people's publishing house,2010.

[2] The ministry of education on promoting the coordinated development of secondary and higher vocational education guidance [Z]. faculty into no [2011]9,2011-09-20.

[3]Hongmei Yan. The present situation and countermeasure analysis about the coordinated development under the perspective of higher vocational education development $[\mathrm{J}]$. education and vocation,2012(27):16-18.

[4]Huanjia Zhang. The bridging course in vocational structure integration design [J]. chinese vocational and technical education,2006(31):37-39.

[5]Shiguang Shao, Yuemu Wang. Based on the national professional standard in higher vocational course linking strategy $[\mathrm{J}]$. vocational education form,2012(15):24-25.

[6]Yu Li. Consideration about secondary and higher vocational education integration training model [J] . vocational education form,2012(22):54-55. 